\title{
FACTORS LEADING TO A FAILURE OF CONTROL OF GONORRHOEA*
}

\author{
BY \\ R. R. WILLCOX \\ Consultant Venereologist, St. Mary's Hospital, London, and King Edward VII Hospital, Windsor; \\ Member of W.H.O. Expert Panel on Venereal Infections and Treponematoses
}

The trends in the prevalence of venereal diseases in England and Wales have shown a failure to control gonorrhoea. During the pre-sulphonamide era, 1925-1936, no progress was made and more cases were being treated in the clinics at the end of the period than at the beginning. The sulphonamide era showed some improvement, but this was upset by the war and by the developing resistance of the gonococcus to these drugs. By 1945-1946 all-time peak figures were reported in both sexes. In the penicillin era, which began at this time, there was a striking initial fall, although not as pronounced as the fall in cases of syphilis. By 1951 the number of cases reported in females represented only 26.6 per cent. and in males 40.6 per cent. of the previous peak totals. The number of male cases fell still further to 37.8 per cent. in 1954 . Since this time, however, there has been a serious deterioration; by 1960 more cases were being treated than in 1925, indicating an overall failure to control gonorrhoea. This situation, occurring in spite of the availability of a number of other effective antibiotics, confirms the old epidemiological adage that effective treatment alone is not sufficient to control a disease. The problem is not confined to Great Britain and is a worldwide phenomenon. Indeed, in a survey published by the World Health Organization (Willcox, 1961), a recent significant rise was noted in no less than fifteen of 22 countries surveyed.

The present paper studies the factors involved in this failure to control gonorrhoea. The author has drawn freely on the data obtained by the British Co-operative Clinical Group (1956, 1960a, b, 1962).

The reasons for lack of control include:

(1) General factors;

* Paper read at the Section of Epidemiology and Preventive Medicine, Royal Society of Medicine, London, November, 1961.
(2) Social factors, especially in certain problem groups of the population;

(3) Difficulties in defining the reservoir of infection;

(4) Difficulties, which are increasing, in the treatment and management of the disease.

\section{(1) General Factors}

Since the treatment of gonorrhoea has become simplified and complications of the disease have been much reduced, there has been a slackening of interest in both patients and members of the medical profession. Patients are less inclined to take prophylactic measures (Towpik, 1957), and an increasing interval has been noted between the onset of symptoms and seeking medical advice (Lodin, 1955). The widespread use of antibiotics may result in some cases being cured before diagnosis, leaving a hidden source of infection in others, and this is aggravated by self-treatment (Brown, 1961). Similarly, the use of sulphonamides or antibiotics in low doses for various infections may result in the relief of symptoms without cure, leaving the patient still infectious (Tottie, 1956).

Study of gonorrhoea has been rendered difficult by the absence of an animal in which it can be investigated experimentally. Even man is largely unsatisfactory for experimental study because natural immunity to the disease, if any, is apparently slight (Mahoney, Van Slyke, Cutler, and Blum, 1946), and induced immunity has not so far been demonstrated.

Prophylaxis is possible by means of orallyadministered antibiotics or by local measures, but, for good and obvious reasons, has not been used on a sufficient scale to achieve the control of the disease in the community, although it has been of value in selected groups (e.g. in armed forces personnel). Certainly, in the cases included in the British Cooperative Clinical Group 1954 Study, for which 
information was available, precautions had been used in only 5 per cent. of males and in $7 \cdot 2$ per cent. of females (Fig. 1). While these figures might be held to indicate the success of the condom, or rather the dire results of not using it, these results may be biased as they include only a small proportion of the total cases reviewed. No information is available concerning the use of precautions in those who do not get venereal disease.

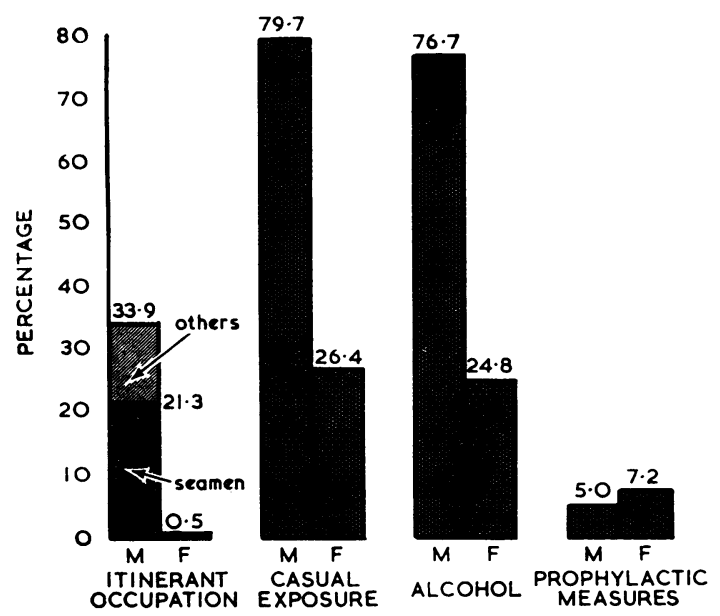

FIG. 1.-Social factors in incidence of gonorrhoea (British Cooperative Clinical Group, 1954 Study).

\section{(2) Social Factors}

(a) General.-Venereal diseases are among those communicable diseases which do not represent a solely medical problem. Their association with times of war and population movement is well known. The influence of the standard of living is less certain. When living standards are very low women turn to prostitution and disease rates are high, but on the other hand peaks of incidence have been noted when standards are high and there is increased spending on alcohol, travel and attendance at bars, cabarets, and places of entertainment linked to prostitution (Gjessing, 1956). However, increased spending may also be devoted to harmless hobbies which leave less opportunity for temptations due to idleness.

The connexion of alcohol with venereal diseases is well known. Alcohol is used to boost facilities for prostitution, and prostitution boosts the sale of alcohol, but social studies of Service men have shown that the decision to seek sexual temptation is often taken before any alcohol has been consumed.
In the British Co-operative Clinical Group Study (1956), $76 \cdot 7$ per cent. of the males and only $24 \cdot 8$ per cent. of the females for which information was available had in fact taken alcohol before the exposure which led to the gonococcal infection. However, proper control figures of alcohol consumption for similar population groups at the same time of day (or night) as the exposure occurred are not available.

Apart from prostitutes and employees of certain restaurants, clubs, bars, and cabarets, who are more than usually exposed to the risks of venereal infection, travellers and migrants of all sorts, including seamen and servicemen away from home, are more prone because they are out of their normal environment.

In the same co-operative study it was shown that no less than 2,037 of the 6,004 male patients studied (33.9 per cent.) had an itinerant occupation (seaman, commercial traveller, artiste, tourist, military, etc.), and of these two-thirds were seamen. On the other hand, only six ( 0.5 per cent.) of the 1,153 female patients included were classed as itinerants (Fig. 1).

(b) Repeated Infections. - A world-wide major problem is that of repeated infections. Data from seven large clinics in 1958, published in the C.M.O's Report for 1959 to the Ministry of Health (Brit. J.ce vener. Dis., 1961), indicated that $23 \cdot 1$ per cent. of? infections in males and 19.5 per cent. of infections in females were new infections in patients previously treated during the same year (Table I).

TABLE I

DATA FROM SEVEN LARGE CLINICS, 1958

\begin{tabular}{c|c|c|c|c}
\hline Sex & $\begin{array}{c}\text { No. of } \\
\text { Cases }\end{array}$ & $\begin{array}{c}\text { No. of } \\
\text { Patients }\end{array}$ & \multicolumn{1}{|c|}{$\begin{array}{c}\text { Repeat Infections in } \\
\text { Same Patients }\end{array}$} \\
\hline Male & 8,438 & 6,484 & 1,954 & $\begin{array}{c}\text { Proportion } \\
\text { per cent. }\end{array}$ \\
\hline Female & 1,992 & 1,603 & 389 & $19 \cdot 5$ \\
\hline
\end{tabular}

Similarly, in the British Co-operative Clinical Group Study (1956), 10.4 per cent. of males and $7 \cdot 3$ per cent. of females had re-infections during the same year as the original attack; $47 \cdot 2$ per cent. of the males and 39.3 per cent. of the females who had one repeat infection had at least one further reinfection still during the same year. Indeed, significant numbers of patients are re-infected during the 
comparatively short period of 3 months' observation after treatment (Table II and Fig. 2).

\section{TABLE II}

\begin{tabular}{|c|c|c|}
\hline \multirow{2}{*}{ Time of Recurrence after Treatment } & \multicolumn{2}{|c|}{ Race } \\
\hline & Non-White & White \\
\hline $\begin{array}{l}0 \\
1-3 \text { days } \\
4-7 \text { days } \\
8-14 \text { days } \\
15-21 \text { days } \\
22-28 \text { days } \\
1-2 \text { mths } \\
2-3 \text { mths } \\
\text { Over } 3 \text { mths }\end{array}$ & $\begin{array}{l}- \\
\overline{0.5} \\
1.9 \\
3.3 \\
3.6 \\
6.6 \\
8.0 \\
11.0\end{array}$ & $\begin{array}{l}\text { 二 } \\
\overline{1} \\
1 \cdot 0 \\
1 \cdot 7 \\
2 \cdot 7 \\
3 \cdot 4 \\
4 \cdot 8 \\
7 \cdot 2\end{array}$ \\
\hline
\end{tabular}

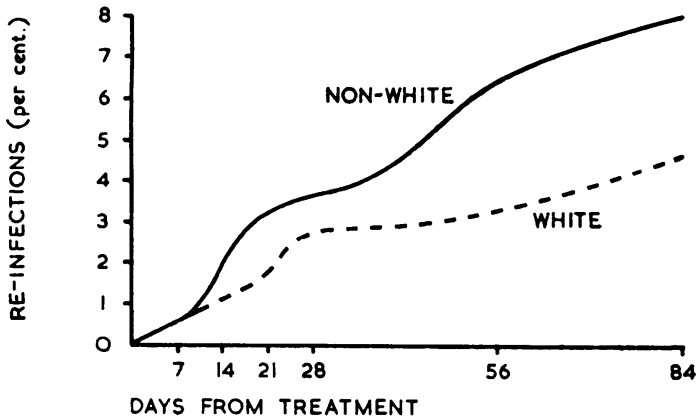

FIG. 2.-Re-infections in patients under observation after treatment for gonorrhoea.

These figures refer to re-infections during only a short period. Figures for previous attacks of gonorrhoea at any time are given in Table III.

TABLE III

PREVIOUS ATTACKS OF GONORRHOEA (MALE PATIENTS IN LONDON)

\begin{tabular}{|c|c|c|c|c|c|c|c|}
\hline Years & $\cdots$ & $\cdots$ & $\cdots$ & $\cdots$ & $\begin{array}{c}1953- \\
1955\end{array}$ & $\begin{array}{c}1956- \\
1958\end{array}$ & $\begin{array}{c}1959- \\
1961\end{array}$ \\
\hline \multicolumn{2}{|l|}{ Total Patients } & $\cdots$ & $\ldots$ & $\ldots$ & 515 & 650 & 578 \\
\hline \multirow{5}{*}{$\begin{array}{l}\text { Previous } \\
\text { Attacks of } \\
\text { Gonorrhoea }\end{array}$} & No ... & $\cdots$ & $\cdots$ & $\cdots$ & 233 & 286 & 236 \\
\hline & \multirow{2}{*}{ Yes } & \multicolumn{3}{|c|}{ Number of Cases } & 282 & 364 & 342 \\
\hline & & Per c & & $\cdots$ & $54 \cdot 8$ & $56 \cdot 0$ & $59 \cdot 2$ \\
\hline & \multicolumn{3}{|c|}{ Number of Attacks } & . & 448 & 862 & 1,044 \\
\hline & \multicolumn{4}{|c|}{ Average Attacks per Patient } & $1 \cdot 6$ & $2 \cdot 4$ & $3 \cdot 1$ \\
\hline
\end{tabular}

Over one half of the male gonorrhoea patients seen in a London clinic had previously had gonorrhoea, and the proportion increased from 54.8 per cent. in the years $1953-1955$ to $59 \cdot 2$ per cent. in 1959-1961. In the same period the average number of previous attacks rose from 1.6 to $3 \cdot 1$. These figures refer to gonorrhoea only and exclude the many attacks of non-gonococcal urethritis and other conditions that had also been contracted.

Table IV shows the number of previous attacks suffered by the 578 patients seen in 1959-1961 listed in Table III, distinguishing their country of origin (West Indies, United Kingdom, and Other Countries). This Table shows that relatively small numbers of patients account for a disproportionate number of previous infections. Thus, only $10 \cdot 3$ per cent. of West Indian patients (who had had seven or more attacks each) accounted for no less than $48 \cdot 3$ per cent. of the previous attacks, $8 \cdot 3$ per cent. of the United Kingdom patients (who had previously had three or more attacks of gonorrhoea) accounted for 51 per cent. of previous infections, while a similar percentage of those in other ethnic groups accounted for 59.8 per cent. The greatest numbers of previous attacks were encountered in the West Indians, 5.2 per cent. of whom had had ten or more attacks, and a number of whom had had over twenty.

TABLE IV

FREQUENCY OF PREVIOUS ATTACKS OF GONORRHOEA IN PATIENTS ATTENDING A LONDON CLINIC (1959-1961),

\begin{tabular}{|c|c|c|c|c|c|c|c|}
\hline \multirow{2}{*}{$\begin{array}{c}\text { Country } \\
\text { of } \\
\text { Origin }\end{array}$} & \multirow{2}{*}{$\begin{array}{l}\text { No. of } \\
\text { Previous } \\
\text { Attacks }\end{array}$} & \multicolumn{3}{|c|}{ Patients } & \multicolumn{3}{|c|}{ Previous Attacks } \\
\hline & & No. & $\begin{array}{l}\text { Cumu- } \\
\text { lative } \\
\text { No. }\end{array}$ & $\begin{array}{c}\text { Total } \\
\text { Per } \\
\text { cent. }\end{array}$ & No. & $\begin{array}{c}\text { Cumu- } \\
\text { lative } \\
\text { No. }\end{array}$ & $\begin{array}{c}\text { Total } \\
\text { Per } \\
\text { cent. }\end{array}$ \\
\hline $\begin{array}{c}\text { West } \\
\text { Indies }\end{array}$ & $\begin{array}{c}0 \\
1 \\
2 \\
3 \\
4 \\
5 \\
6 \\
7 \\
8 \\
9 \\
10-19 \\
20 \text { or } \\
\text { More }\end{array}$ & $\begin{array}{r}72 \\
81 \\
54 \\
20 \\
16 \\
9 \\
8 \\
7 \\
2 \\
6 \\
10 \\
5\end{array}$ & $\begin{array}{r}290 \\
218 \\
137 \\
83 \\
63 \\
47 \\
38 \\
30 \\
23 \\
21 \\
15 \\
5\end{array}$ & $\begin{array}{r}100.0 \\
75.2 \\
47.3 \\
28.6 \\
21.7 \\
16.2 \\
13.1 \\
10.3 \\
7.9 \\
7.2 \\
5.2 \\
1.7\end{array}$ & $\begin{array}{r}\overline{81} \\
108 \\
60 \\
64 \\
45 \\
48 \\
49 \\
16 \\
54 \\
144 \\
117\end{array}$ & $\begin{array}{l}\overline{786} \\
705 \\
597 \\
537 \\
473 \\
428 \\
380 \\
331 \\
315 \\
261 \\
117\end{array}$ & $\begin{array}{r}100 \cdot 0 \\
89 \cdot 7 \\
76 \cdot 0 \\
68 \cdot 3 \\
60 \cdot 2 \\
54 \cdot 5 \\
48 \cdot 3 \\
42 \cdot 1 \\
40 \cdot 1 \\
33 \cdot 2 \\
14 \cdot 9\end{array}$ \\
\hline $\begin{array}{c}\text { United } \\
\text { Kingdom }\end{array}$ & $\begin{array}{c}0 \\
1 \\
2 \\
3 \\
4 \\
5 \\
6 \\
7 \\
10^{-19}\end{array}$ & $\begin{array}{r}90 \\
54 \\
10 \\
5 \\
2 \\
1 \\
3 \\
1 \\
2\end{array}$ & $\begin{array}{r}168 \\
78 \\
24 \\
14 \\
9 \\
7 \\
6 \\
3 \\
2\end{array}$ & $\begin{array}{r}100.0 \\
46.4 \\
14.3 \\
8.3 \\
5.4 \\
4.2 \\
3.6 \\
1.8 \\
1.2\end{array}$ & $\begin{array}{r}\overline{54} \\
20 \\
15 \\
8 \\
5 \\
18 \\
7 \\
24\end{array}$ & $\begin{array}{r}151 \\
97 \\
77 \\
62 \\
54 \\
49 \\
31 \\
24\end{array}$ & $\begin{array}{r}\overline{100.0} \\
64.2 \\
51.0 \\
41.1 \\
35.8 \\
32.5 \\
20.5 \\
15.9\end{array}$ \\
\hline Other & $\begin{array}{c}0 \\
1 \\
2 \\
3 \\
4 \\
5 \\
8 \\
10-19 \\
20 \text { or } \\
\text { More }\end{array}$ & $\begin{array}{r}74 \\
29 \\
7 \\
4 \\
2 \\
1 \\
1 \\
1 \\
1\end{array}$ & $\begin{array}{r}120 \\
46 \\
17 \\
10 \\
6 \\
4 \\
3 \\
2 \\
1\end{array}$ & $\begin{array}{r}100.0 \\
38.3 \\
14.2 \\
8.3 \\
5.0 \\
3.3 \\
2.5 \\
1.7 \\
0.8\end{array}$ & $\begin{array}{r}29 \\
14 \\
12 \\
8 \\
5 \\
8 \\
11 \\
20\end{array}$ & $\begin{array}{r}107 \\
78 \\
64 \\
52 \\
44 \\
39 \\
31 \\
20\end{array}$ & $\begin{array}{r}1 \overline{100.0} \\
72.9 \\
59.8 \\
48.6 \\
41.1 \\
37.4 \\
29.0 \\
18.7\end{array}$ \\
\hline
\end{tabular}

Other countries report similar experience. Brown (1961) noted that, of 1,000 patients with gonorrhoea treated in the U.S.A., 80 per cent. had had a previous venereal infection, and 26 per cent. returned with a new infection within 6 months. Several studies have 
been carried out of the psychological and socioeconomic circumstances of persons with repeated infections (Boese, 1953; Lentz, Morton, Garrison, and Leberman, 1953), and it has been shown that in many instances the intelligence of "repeaters" was below normal (Bundesen, Plotke, and Eisenberg, 1949).

(c) Immigrants.-Persons entering a country in search of work because of the poor economic or political prospects in their own homelands are a particular problem, from the point of view of venereal diseases, in many countries because large bodies of sexually active males are confronted with strange circumstances without their normal female sexual outlet.

The importance of such groups in England and Wales is indicated in Table V, which shows the country of origin of patients treated for gonorrhoea in 1960 (British Co-operative Clinical Group, 1960a). This distribution is summarized in Fig. 3.

TABLE V

COUNTRY OF ORIGIN OF GONORRHOEA CASES TREATED IN ENGLAND AND WALES, 1960, BY SEX

\begin{tabular}{c|r|r|r|r}
\hline \multirow{2}{*}{ Country of Origin } & \multicolumn{2}{|c|}{ Male } & \multicolumn{2}{c}{ Female } \\
\cline { 2 - 5 } \cline { 4 - 5 } & \multicolumn{1}{|c|}{ No. } & Per cent. & \multicolumn{1}{c}{ No. } & Per cent. \\
\hline West Indies & 5,515 & $25 \cdot 5$ & 466 & $7 \cdot 9$ \\
West Africa & 699 & $3 \cdot 2$ & 14 & $0 \cdot 2$ \\
Other Negro & 101 & $0 \cdot 5$ & 12 & $0 \cdot 2$ \\
Asia & 1,184 & $5 \cdot 5$ & 41 & $0 \cdot 7$ \\
Mediterranean & 1,115 & $5 \cdot 1$ & 52 & $0 \cdot 9$ \\
United Kingdom & 10,719 & $49 \cdot 5$ & 4,905 & $83 \cdot 0$ \\
Eire & 1,116 & $5 \cdot 1$ & 275 & $4 \cdot 7$ \\
Europe & 929 & $4 \cdot 3$ & 121 & $2 \cdot 0$ \\
Other White & 285 & $1 \cdot 3$ & 26 & 0.4 \\
\hline Total & 21,663 & $100 \cdot 0$ & 5,912 & $100 \cdot 0$ \\
\hline
\end{tabular}
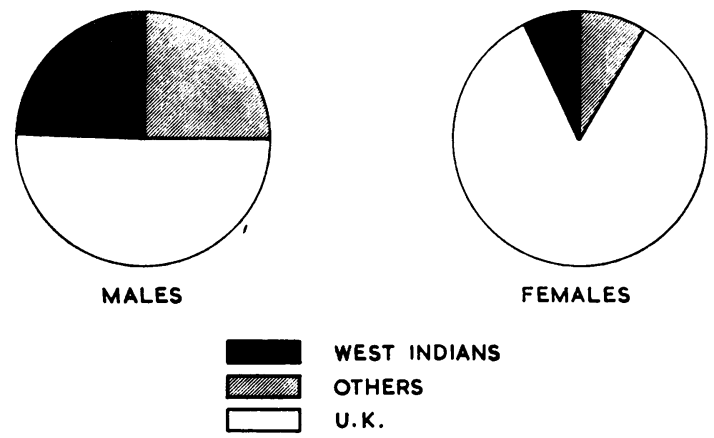

FIG. 3.-Country of origin of gonorrhoea patients, 1960.

Persons born in the United Kingdom accounted for half the male cases. The largest other single group was that of the West Indians ( 25.5 per cent.) and Asians, those born in the Mediterranean region, in Eire, and in Europe comprised about 5 per cent. each. West Africans, Other Negroes, and Other
Whites taken together accounted for only another 5 per cent.

Among females those born in the United Kingdom accounted for no less than 83 per cent. of cases. West Indians were the next highest single group ( $7 \cdot 9$ per cent.), followed by Eire ( 4.7 per cent.) and other Europeans ( 2 per cent.). The remaining five groups together comprised only 2.4 per cent.

The immigrant West Indian is frequently blamed for much of the venereal disease problem in Great Britain. Certainly West Indians have been responsible for an increasing proportion of gonorrhoea in both sexes, especially in males. A comparison of the proportion of patients from the West Indies in five different years since 1952 as found in the British Co-operative Clinical Group studies is shown in Table VI.

TABLE VI

CHANGING PROPORTIONS OF COUNTRY OF ORIGIN OF GONORRHOEA CASES, BY SEX

\begin{tabular}{|c|c|c|c|c|c|c|}
\hline \multirow{2}{*}{ Sex } & \multirow{2}{*}{$\begin{array}{c}\text { Country } \\
\text { of } \\
\text { Origin }\end{array}$} & \multicolumn{5}{|c|}{ Year } \\
\hline & & 1952 & 1954 & 1955 & 1958 & 1960 \\
\hline \multirow[t]{2}{*}{ Male } & $\begin{array}{l}\text { West Indies } \\
\text { Other } \quad \ldots \\
\text { U.K. }\end{array}$ & $\begin{array}{r}3 \cdot 0 \\
27 \cdot 3 \\
69 \cdot 7\end{array}$ & $\begin{array}{r}7 \cdot 5 \\
30 \cdot 0 \\
62 \cdot 5\end{array}$ & $\begin{array}{r}5 \cdot 9 \\
26 \cdot 8 \\
67 \cdot 3\end{array}$ & $\begin{array}{l}24 \cdot 0 \\
24 \cdot 5 \\
51 \cdot 5\end{array}$ & $\begin{array}{l}25 \cdot 5 \\
25 \cdot 0 \\
49 \cdot 5\end{array}$ \\
\hline & Totals & $100 \cdot 0$ & $100 \cdot 0$ & $100 \cdot 0$ & $100 \cdot 0$ & $100 \cdot 0$ \\
\hline \multirow[t]{2}{*}{ Female } & $\begin{array}{l}\text { West Indies } \\
\text { Other } \quad \ldots \\
\text { U.K. } \quad \ldots\end{array}$ & $\begin{array}{r}0 \cdot 5 \\
4 \cdot 7 \\
94 \cdot 8\end{array}$ & $\begin{array}{r}1 \cdot 2 \\
7 \cdot 6 \\
91 \cdot 2\end{array}$ & $\begin{array}{r}1 \cdot 1 \\
6 \cdot 5 \\
92 \cdot 4\end{array}$ & $\begin{array}{r}5 \cdot 9 \\
5 \cdot 4 \\
88 \cdot 7\end{array}$ & $\begin{array}{r}7 \cdot 9 \\
9 \cdot 1 \\
83 \cdot 0\end{array}$ \\
\hline & Totals & $100 \cdot 0$ & $100 \cdot 0$ & $100 \cdot 0$ & $100 \cdot 0$ & $100 \cdot 0$ \\
\hline
\end{tabular}

From this it is evident that there has been a striking increase in the proportion of West Indians, from 3 per cent. of male cases in 1952 to 25.5 per cent. in 1960. The data obtained from 84 clinics has been analysed for the years 1952 to 1958, during which time there was an increase of 2,020 male and 599 female cases in these clinics. The proportion of this increase which was due to West Indians, persons born in the United Kingdom, and others, is shown in Table VII and Fig. 4 (opposite).

TABLE VII

PERCENTAGE OF INCREASE BETWEEN THE YEARS 1952 AND 1958 IN WEST INDIANS AND OTHERS, BY SEX

\begin{tabular}{c|r|r}
\hline \multirow{2}{*}{ Country of Origin } & \multicolumn{2}{|c}{ Sex } \\
\cline { 2 - 3 } & Male & Female \\
\hline West Indies & $54 \cdot 9$ & $14 \cdot 7$ \\
Other & 27.8 & 6.7 \\
U.K. & 17.3 & 78.6 \\
\hline Total & $100 \cdot 0$ & $100 \cdot 0$ \\
\hline
\end{tabular}




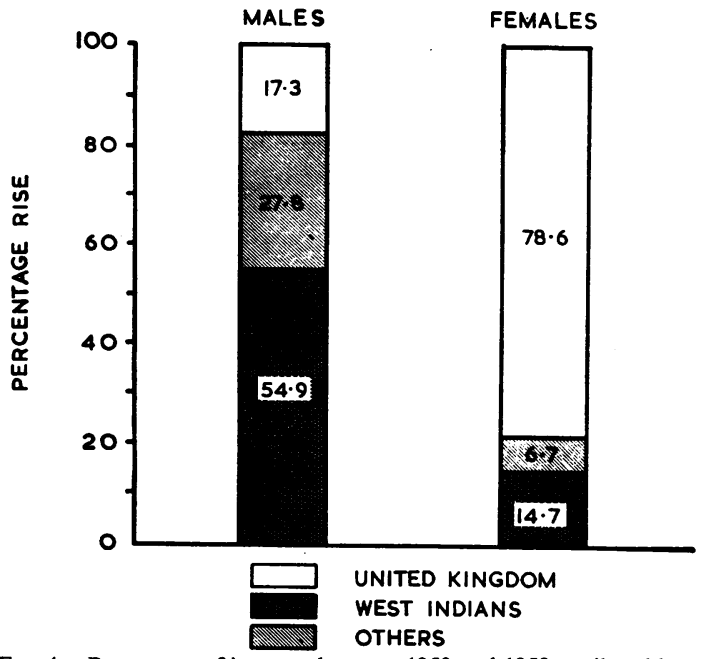

Fig. 4.-Percentage of increase between 1952 and 1958 attributable to West Indians and other patients.

West Indians were responsible for over half of the male increase between 1952 and 1958, and the United Kingdom for a much smaller proportion. Only $14 \cdot 7$ per cent. of the increase in females was due to West Indians. The figures suggest, therefore, that if there were no West Indian immigrants at all there would still be an increase in gonorrhoea.

There is no doubt that the venereal disease rates in the West Indian immigrants are very high. A calculation based on the estimated number of West Indians in Great Britain in 1958 (115,000, of which 100,000 were assumed to be males) gave a venereal disease rate of 36.9 per 1,000 for males and 12 per 1,000 for females, whereas for persons of similar age groups born in the United Kingdom (i.e. 20-44 years) the rates were only $1 \cdot 1$ per 1,000 and 0.4 per 1,000 respectively. This means that the West Indian rates were at least thirty times those of indigenous persons.

A similar trend is seen in Table VIII, in which the cases of gonorrhoea in persons born in the United Kingdom are calculated from the percentages of such

TABLE VIII

ESTIMATED CASES OF GONORRHOEA IN U.K.-BORN MALES, 1955 AND 1960

\begin{tabular}{c|c|c|c}
\hline \multirow{2}{*}{ Year } & \multirow{2}{*}{$\begin{array}{c}\text { Total } \\
\text { All Races }\end{array}$} & \multicolumn{2}{|c}{ U.K.-Born } \\
\cline { 3 - 4 } & $\begin{array}{c}\text { Proportion } \\
\text { Per cent. }\end{array}$ & Number \\
\hline 1955 & 14,079 & $67 \cdot 3$ & 9,475 \\
1960 & 26,508 & $49 \cdot 5$ & 13,121 \\
Difference & 12,429 & - & 3,646 \\
\hline Per cent. Increase & $88 \cdot 3$ & - & $38 \cdot 5$ \\
\hline
\end{tabular}

persons found in the Co-operative Group Surveys in 1955 and 1960. There has been an increase of 88.3 per cent. in gonorrhoea in males in these 5 years, but for United Kingdom patients only the increase has been 38.5 per cent. This further supports the view that immigrants markedly aggravate the present situation, but are not the only cause of it.

(d) Young Persons.-Venereal disease in young persons is an increasing problem in many lands. Significant increases have been reported in the U.S.A. (Soc. Hyg. News, 1959); in 1957 it was estimated that 49,795 youngsters reported with venereal disease in the U.S.A. (an average of one infection in a person under 20 years of age every 11 minutes). In New York City in 1940, 9.3 per cent. of male gonorrhoea patients and 8.8 per cent. of females belonged to the 15 to 19 -year age group. By 1954 the percentage was still about 9 per cent. for males, but had risen to 18.6 per cent. for females (Rosenthal and Vandow, 1956).

The age groups of male and female gonorrhoea patients as found in the British Co-operative Clinical Group Studies are shown in Table IX.

TABLE IX

AGE DISTRIBUTION OF GONORRHOEA PATIENTS, 1958, BY SEX

\begin{tabular}{|c|c|c|c|c|}
\hline \multirow{3}{*}{ Age (yrs) } & \multicolumn{4}{|c|}{ Sex } \\
\hline & \multicolumn{2}{|c|}{ Male } & \multicolumn{2}{|c|}{ Female } \\
\hline & No. & Per cent. & No. & Per cent. \\
\hline $\begin{array}{l}14 \text { and Under } \\
15-17 \\
18-19 \\
20-24 \\
25-29 \\
30-34 \\
35-39 \\
40 \text { and Over }\end{array}$ & $\begin{array}{r}9 \\
180 \\
915 \\
5,034 \\
4,861 \\
3,044 \\
1,889 \\
2,086\end{array}$ & $\begin{array}{r}\overline{1} \cdot 0 \\
5 \cdot 1 \\
27 \cdot 9 \\
27 \cdot 0 \\
16 \cdot 9 \\
10 \cdot 5 \\
11 \cdot 6\end{array}$ & $\begin{array}{r}29 \\
303 \\
657 \\
1,407 \\
804 \\
481 \\
267 \\
300\end{array}$ & $\begin{array}{r}0 \cdot 7 \\
7 \cdot 1 \\
15 \cdot 5 \\
33 \cdot 1 \\
18 \cdot 9 \\
11 \cdot 3 \\
6 \cdot 3 \\
7 \cdot 1\end{array}$ \\
\hline Totals & 18,018 & $100 \cdot 0$ & 4,248 & $100 \cdot 0$ \\
\hline
\end{tabular}

There were very few patients aged 14 and under, but teenagers of 15 to 19 years old comprised $6 \cdot 1$ per cent. of infections in males and 22.6 per cent. in females, the rate being higher in the 18 to 19-year group than in the 15 to 17 -year group. Those aged 20 to 24 years comprised 27.9 per cent. of males and 33.1 per cent. of females, and those older than 25 years comprised 66 per cent. of the males but only 43. 6 per cent. of the females.

Although patients aged 15 to 19 years are responsible for comparatively few of the total number of infections, there is evidence from the Co-operative 
Group Surveys that their numbers are increasing more quickly than those of the other groups, especially the females (Table $X$ and Fig. 5).

TABLE $\mathbf{X}$

PERCENTAGE INCREASE IN GONORRHOEA BETWEEN 1957 AND 1960, BY AGE GROUP AND SEX (ENGLAND AND WALES ONLY)

\begin{tabular}{|c|c|c|c|c|c|}
\hline \multirow{2}{*}{ Sex } & \multirow{2}{*}{$\underset{\text { (yrs) }}{\text { Age Group }}$} & \multicolumn{2}{|c|}{ Year } & \multirow{2}{*}{ Difference } & \multirow{2}{*}{$\begin{array}{l}\text { Percentage } \\
\text { Increase }\end{array}$} \\
\hline & & 1957 & 1960 & & \\
\hline \multirow[t]{2}{*}{ Male } & $\begin{array}{c}15-19 \\
20-24 \\
25 \text { and Over }\end{array}$ & $\begin{array}{r}828 \\
4,171 \\
10,309\end{array}$ & $\begin{array}{r}1,385 \\
6,516 \\
13,762\end{array}$ & $\begin{array}{l}+557 \\
+2,345 \\
+3,453\end{array}$ & $\begin{array}{l}+67.3 \\
+56.2 \\
+33.5\end{array}$ \\
\hline & Totals & 15,308 & 21,663 & $+6,355$ & $41 \cdot 5$ \\
\hline \multirow[t]{2}{*}{ Female } & $\begin{array}{c}15-19 \\
20-24 \\
25 \text { and Over }\end{array}$ & $\begin{array}{r}939 \\
1,377 \\
1,816\end{array}$ & $\begin{array}{l}1,553 \\
2,216 \\
2,143\end{array}$ & $\begin{array}{r}+\quad 614 \\
+\quad 839 \\
+\quad 327\end{array}$ & $\begin{array}{l}+65.4 \\
+60.9 \\
+18.0\end{array}$ \\
\hline & Totals & 4,132 & 5,912 & $+1,780$ & $43 \cdot 1$ \\
\hline
\end{tabular}

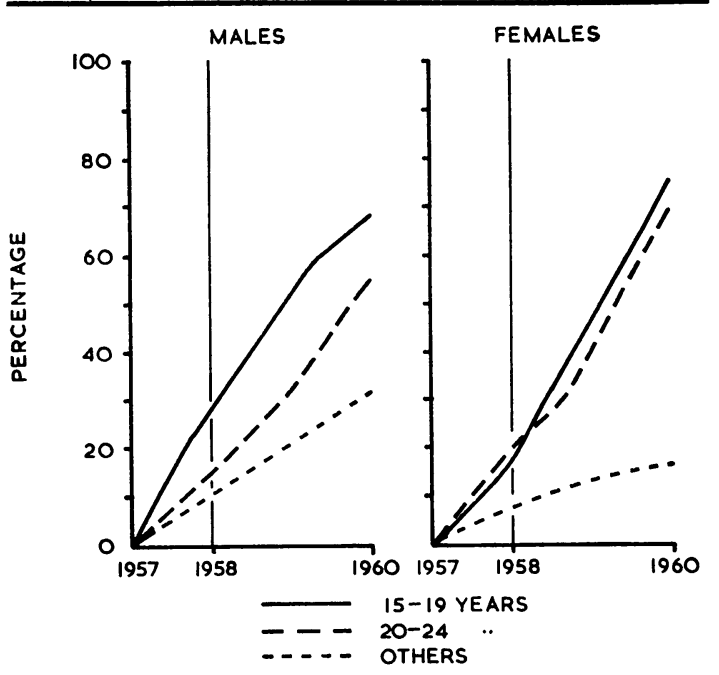

FIG. 5.-Rate of increase of gonorrhoea, 1957-1960, by age groups. Percentage increase on 1957 figures.

Between 1957 and 1960 the numbers of infections in 15 to 19 -year-olds rose by $67 \cdot 3$ per cent. in males and by 65.4 per cent. in females, whereas the rise in persons aged 25 and over was only 33.5 and 18 per cent. respectively.

It may be argued that this increase can be related to the increase in the total population of young persons. A calculation has been made for the years 1957 and 1958 and it is evident that the increase in gonorrhoea was out of all proportion to the relatively much smaller increase which had occurred in the population as a whole (Table XI).

In the two years concerned the total population rose by only 0.4 per cent., whereas infectious venereal disease $(96 \cdot 1$ per cent. of it gonorrhoea) rose by 13 per cent.
TABLE XI

PERCENTAGE INCREASE IN POPULATION COMPARED WITH PERCENTAGE INCREASE IN CASES OF INFECTIOUS V.D. BETWEEN 1957 AND 1958, BY AGE GROUP

\begin{tabular}{|c|c|c|c|}
\hline \multirow{2}{*}{\multicolumn{2}{|c|}{ Age (yrs) }} & \multicolumn{2}{|c|}{$\begin{array}{c}\text { Percentage Increase between } \\
1957 \text { and } 1958\end{array}$} \\
\hline & & Population & Infectious V.D. \\
\hline & $\begin{array}{l}14 \text { and Under } \\
15-19 \\
20-24 \\
25-34 \\
35 \text { and Over }\end{array}$ & $\begin{array}{l}+0.7 \\
+2.0 \\
+1.3 \\
-1.6 \\
+0.6\end{array}$ & $\begin{array}{l}+100.0 \\
+\quad 21.0 \\
+16.5 \\
+\quad 11.5 \\
+\quad 7.6\end{array}$ \\
\hline Total .. & $\begin{array}{ll} & \ldots\end{array}$ & +0.4 & $+13 \cdot 0$ \\
\hline
\end{tabular}

In an attempt to eliminate the effect of immigration and other factors, a calculation has been made of the actual numbers of gonorrhoea patients aged 15 to 19 years who were born in the United Kingdom, on the assumption that the findings of the British Cooperative Clinical Group Surveys are representative of the whole (Table XII). This estimate suggests that the number of U.K. patients aged 15 to 19 years increased by $19 \cdot 3$ per cent. (704 to 840 ) in males and by $36 \cdot 1$ per cent. in females $(1,144$ to 1,557$)$.

TABLE XII

ESTIMATED NUMBERS OF U.K.-BORN GONORRHOEA PATIENTS AGED 15-19 YEARS IN 1958 AND 1960,

\begin{tabular}{|c|c|c|c|c|c|c|c|}
\hline \multirow{2}{*}{$\begin{array}{l}\text { Sex } \\
\text { Year }\end{array}$} & \multirow{2}{*}{$\begin{array}{ll}\cdot & \cdots \\
& .\end{array}$} & \multirow{2}{*}{$\frac{\cdots}{\ldots}$} & \multirow{2}{*}{$\begin{array}{l}\ldots \\
\ldots\end{array}$} & \multicolumn{2}{|c|}{ Male } & \multicolumn{2}{|c|}{ Female } \\
\hline & & & & 1958 & 1960 & 1958 & 1960 \\
\hline \multicolumn{2}{|c|}{ Total All Races } & . & $\ldots$ & 22,398 & 26,508 & 5,489 & 7,132 \\
\hline \multirow{2}{*}{$\begin{array}{l}\text { U.K.- } \\
\text { born }\end{array}$} & \multicolumn{3}{|c|}{$\begin{array}{l}\text { Percentage } \\
\text { Estimated No. }\end{array}$} & $\begin{array}{c}51 \cdot 5 \\
11,535\end{array}$ & $\begin{array}{c}49 \cdot 5 \\
13,121\end{array}$ & $\begin{array}{l}88 \cdot 7 \\
4,869\end{array}$ & $\begin{array}{l}83 \cdot 0 \\
5,920\end{array}$ \\
\hline & \multicolumn{3}{|c|}{$\begin{array}{l}\text { Percentage aged } 15 \\
\text { to } 19 \text { yrs } \\
\text { Estimated No. aged } \\
15 \text { to } 19 \text { yrs } \quad \ldots\end{array}$} & $\begin{array}{c}6 \cdot 1 \\
704\end{array}$ & $\begin{array}{c}6 \cdot 4 \\
840\end{array}$ & $\begin{array}{l}23 \cdot 5 \\
1,144\end{array}$ & $\begin{array}{l}26 \cdot 3 \\
1,557\end{array}$ \\
\hline
\end{tabular}

In males this estimated increase between 1958 and 1960 was responsible for only 8.6 per cent. of the corresponding increase for male U.K. patients of all ages. In females the position was far more serious, as this group was responsible for no less than $39 \cdot 3$ per cent. of the total increase in female patients from the United Kingdom (Table XIII, opposite). Striking though this proportion is, the fact remains that, if there had been no increase in the 15 to 19 -year-olds, there would still have been an increase in the incidence of gonorhoea.

The problem of venereal disease in the young is part of a pattern which includes increasing pregnancies at a young age, increasing crimes of violence and against property, and a certain attitude to life in general (Association of State and Territorial Health Officers, American Venereal Disease Association, and American Social Hygiene Association, 1959), 
TABLE XIII

ESTIMATED PERCENTAGE INCREASE BETWEEN 1958 AND 1960 IN U.K.-BORN GONORRHOEA PATIENTS IN 15 TO 19-YEAR AGE GROUP, BY SEX

\begin{tabular}{|c|c|c|c|c|c|}
\hline \multirow{2}{*}{\multicolumn{4}{|c|}{ U.K.-born Patients }} & \multicolumn{2}{|c|}{ Sex } \\
\hline & & & & \multirow{2}{*}{$\begin{array}{c}\text { Male } \\
11,535 \\
13,121\end{array}$} & \multirow{2}{*}{$\begin{array}{c}\text { Female } \\
4,869 \\
5,920\end{array}$} \\
\hline Estimated Number & . & .. & $\begin{array}{l}1958 \\
1960\end{array}$ & & \\
\hline Increase & . & . & . & 1,586 & 1,051 \\
\hline \multicolumn{3}{|c|}{$\begin{array}{l}\text { Increase in } 15 \text { to } 19 \text {-year-olds } \\
\text { Increase in Other Age Groups }\end{array}$} & 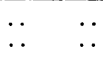 & $\begin{array}{r}136 \\
1,450\end{array}$ & $\begin{array}{l}413 \\
638\end{array}$ \\
\hline \multicolumn{4}{|c|}{ Percentage of Increase in 15 to 19 -year-olds } & $8 \cdot 6$ & $39 \cdot 3$ \\
\hline
\end{tabular}

and is a matter of great concern for the sociologist. The relative importance of these two problems, West Indian males and U.K. females, are summarized in Fig. 6.

WEST INDIAN MALES

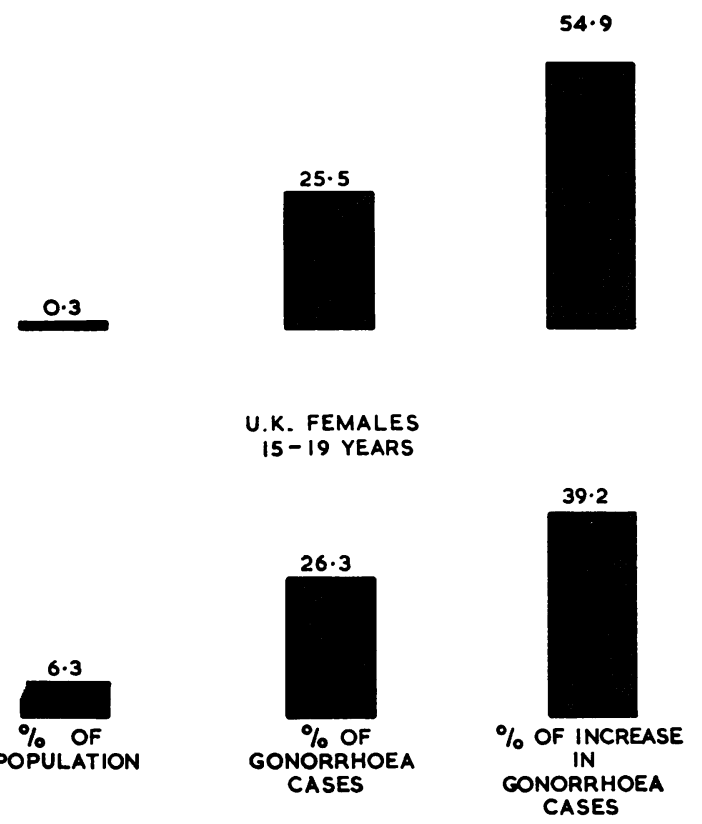

FIG. 6.-Two major problems: West Indian males and young United Kingdom females.

\section{(3) Difficulties in Defining the Reservoir OF INFECTION}

The failure to define the reservoir of infection, which lies in the undiagnosed female, is indicated by the fact that the number of reported male cases is several times that of the female (Nelson, 1957). Moreover, the proportion of men infected by unknown partners is rising in some countries.

(a) Nature of Source of Infection.-The source of infection in over 6,000 cases of gonorrhoea treated in England and Wales in 1954 (British Co-operative Clinical Group, 1956) is shown in Table XIV and Fig. 7.

TABLE XIV

SOURCE OF INFECTION, BY SEX

\begin{tabular}{c|r|r|r|r}
\hline \multirow{2}{*}{ Nature of Source } & \multicolumn{2}{|c|}{ Male } & \multicolumn{2}{c}{ Female } \\
\cline { 2 - 3 } \cline { 2 - 4 } & \multicolumn{1}{|c|}{ No. } & Per cent. & No. & Per cent. \\
\hline Prostitute & 1,893 & $35 \cdot 7$ & 2 & $0 \cdot 2$ \\
Casual Acquaintance & 2,201 & $41 \cdot 5$ & 289 & $26 \cdot 2$ \\
Friend & 868 & $16 \cdot 4$ & 466 & $42 \cdot 2$ \\
Marital & 210 & $3 \cdot 9$ & 348 & $31 \cdot 4$ \\
Homosexual & 130 & $2 \cdot 5$ & - & - \\
\hline Total & 5,302 & $100 \cdot 0$ & 1,105 & $100 \cdot 0$ \\
\hline Total Casual & 4,224 & $79 \cdot 7$ & 291 & $26 \cdot 4$ \\
\hline
\end{tabular}

PROSTITUTE

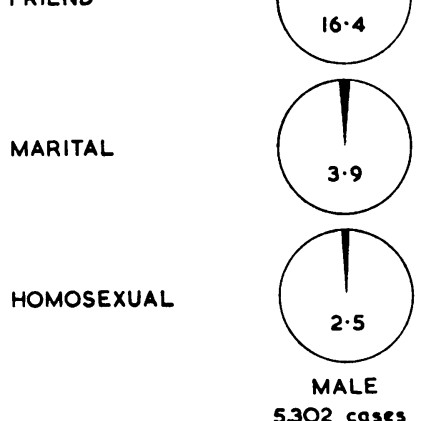

302 cases operative Clinical Group, 1954 Study).

The prostitute was responsible for only $35 \cdot 7$ per cent. of the male and practically none of the female infections. In the male, therefore, the majority of infections were not due to prostitutes, and in this respect the Western countries (and especially the U.S.A. and Canada) differ from the countries of Asia, Africa, and South America (Willcox, 1958), where the great majority of venereal diseases result from intercourse with prostitutes. In most Western 
countries the prostitute is steadily being replaced by the "good-time girl", who is now responsible for the bulk of gonococcal infections in the male $(41.5$ per cent. in this series), while only $26 \cdot 2$ per cent. of infections in the more discriminating female resulted from casual exposure. It follows, therefore, that in countries such as Great Britain repressive measures against prostitution will have less effect on the spread of gonorrhoea. The rise in incidence has occurred in spite of the Street Offences Act, although the situation would doubtless be far worse without it. Indeed, in Manchester, the Act has been credited with a decline in the incidence of gonorrhoea (Laird, 1961).

Known "friends" accounted for 16.4 per cent. of infections in the male and marital intercourse for only 3.9 per cent. In the female, on the other hand, a total of 73.6 per cent. of infections $(42.2$ per cent. from "friends" and 31.4 per cent. from husbands) resulted from known and presumably trusted consorts.

In the female homosexuality was not a proven source of gonorrhoeal infection, and in the male it accounted for only $2 \cdot 5$ per cent. of cases.

(b) Tracing the Source.-In Great Britain the principal case-finding tool for tracing the female contacts of male patients is the contact slip. This has very definite limitations, and less than 20 per cent. of patients may be traced in a particular clinic by this means irrespective of the number of slips issued (Table XV and Fig. 8). Nevertheless, these figures may underestimate the value of the method, as some contacts may attend the same or other clinics without declaring the exact reason for their attendance.

TABLE XV

VALUE OF GONORRHOEA CONTACT SLIPS IN TWO LONDON CLINICS

\begin{tabular}{|c|c|c|c|c|}
\hline Clinic & .. & . & $\begin{array}{l}1951-1953 \\
\text { (1) }\end{array}$ & $\begin{array}{c}1960 \\
\text { (2) }\end{array}$ \\
\hline $\begin{array}{l}\text { Percent } \\
\text { Percent } \\
\text { Percent }\end{array}$ & $\begin{array}{l}\text { age Patients } \\
\text { age Slips Issued } \\
\text { age Contacts Traced }\end{array}$ & $\begin{array}{l}\cdots \\
\cdots \\
\cdots\end{array}$ & $\begin{array}{r}100 \\
78 \\
18\end{array}$ & $\begin{array}{r}100 \\
35 \\
14\end{array}$ \\
\hline
\end{tabular}

(1) Haworth and Nicol (1954)

(2) Personal data

(c) Difficulties in Diagnosis.-Even when the suspected female source is found, difficulties in diagnosis remain. Symptomless gonorrhoeal infections are not uncommon in the female. Furthermore, even in expert hands, the bacteriological techniques are uncertain, and many examinations may be required to

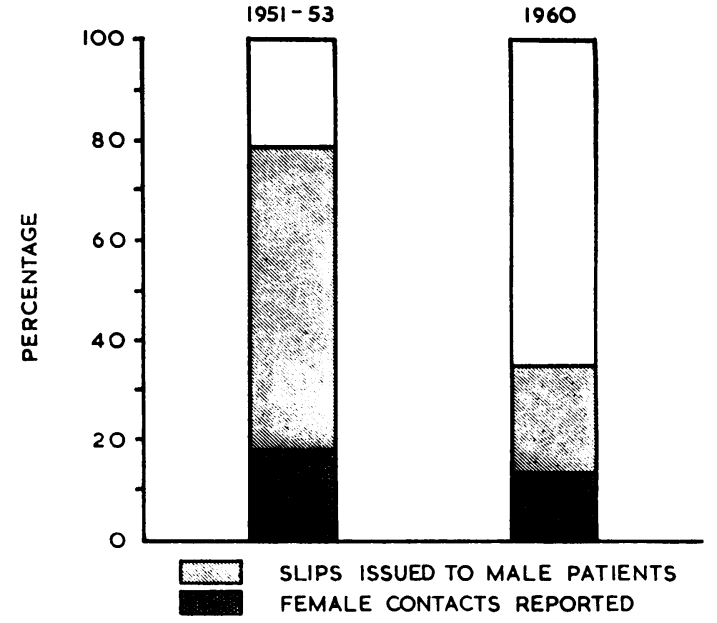

Fig. 8.-Value of contact slips in London: 1951-53 (Haworth and Nicol, 1954) and 1960 (Personal data).

identify the organism in an infected woman. Indeed, so unreliable are the present methods of diagnosis in the female, that for many years it has been considered unwise to refrain from treating suspected persons in whom the tests at first prove negative.

\section{(4) Difficulties in Treatment}

The lessened sensitivity of the gonococcus to penicillin (the detailed consideration of which is beyond the scope of this paper) has resulted in increasing failure rates with doses and preparations of penicillin which were once successful (Table XVI).

TABLE XVI

\section{INCREASING FAILURE RATES WITH PROCAINE PENICILLIN IN OIL WITH ALUMINIUM MONOSTEARATE (P.A.M.) IN LONDON, 1952-1957}

\begin{tabular}{c|c|c|c|c|c|c}
\hline Year & $\begin{array}{c}\text { Dose } \\
\text { (mega } \\
\text { units) }\end{array}$ & $\begin{array}{c}\text { No. } \\
\text { Treated }\end{array}$ & $\begin{array}{c}\text { No. } \\
\text { Followed }\end{array}$ & $\begin{array}{c}\text { No. of } \\
\text { Failures }\end{array}$ & $\begin{array}{c}\text { Re-infec- } \\
\text { tions }\end{array}$ & $\begin{array}{c}\text { Percentage } \\
\text { Failures } \\
\text { of those } \\
\text { Followed }\end{array}$ \\
\hline 1952 & $0 \cdot 15$ & 223 & 200 & 18 & 42 & $9 \cdot 0$ \\
1954 & $0 \cdot 30$ & 226 & 194 & 9 & 22 & 4.6 \\
1955 & $0 \cdot 60$ & 226 & 190 & 34 & 23 & 17.9 \\
1957 & $1 \cdot 20$ & 44 & 39 & 7 & 15 & 17.9 \\
\hline Totals & - & 719 & 623 & 68 & 102 & \\
\hline
\end{tabular}

Although cases of complete resistance are not being encountered with penicillin (cases will still respond if enough is given) there have been increased failure rates with repository preparations. This has necessitated a switch to shorter-acting preparations (e.g. aqueous procaine penicillin) to provide a higher peak of penicillinaemia to overcome the less sensitive strains. Such strains, probably related to treatment 
practices, are distributed irregularly in place and time.

Strains of gonococci which are resistant to streptomycin are also increasing and these prove to be completely resistant.

The next major difficulty in case management is case-holding. The degree of follow-up which may be expected in a capital city like London is shown in Table XVII and Fig. 9. In the series shown, 18.6 per cent. of males and 26 per cent. of females never returned to the clinic after the initial visit and treatment, and only $42 \cdot 8$ per cent. of males and 53 per cent. of females could be followed for periods exceeding one week.

TABLE XVII

FOLLOW-UP OF GONORRHOEA CASES IN A CAPITAL CITY

\begin{tabular}{|c|c|c|c|c|}
\hline \multirow{3}{*}{$\begin{array}{l}\text { Follow-up } \\
\text { Period }\end{array}$} & \multicolumn{4}{|c|}{ Sex } \\
\hline & \multicolumn{2}{|l|}{ Male } & \multicolumn{2}{|c|}{ Female } \\
\hline & No. Followed & Per cent. & No. Followed & Per cent. \\
\hline $\begin{array}{c}0 \\
1-3 \text { days } \\
4-7 \text { days } \\
8-14 \text { days } \\
15-21 \text { days } \\
22-28 \text { days } \\
1-2 \text { mths } \\
2-3 \text { mths } \\
\text { Over } 3 \text { mths }\end{array}$ & $\begin{array}{r}561 \\
538 \\
415 \\
283 \\
193 \\
142 \\
116 \\
67 \\
38\end{array}$ & $\begin{array}{r}100 \cdot 0 \\
81 \cdot 4 \\
62 \cdot 8 \\
42 \cdot 8 \\
29 \cdot 2 \\
21 \cdot 5 \\
17 \cdot 5 \\
10 \cdot 1 \\
5 \cdot 7\end{array}$ & $\begin{array}{r}100 \\
74 \\
68 \\
53 \\
41 \\
36 \\
31 \\
22 \\
12\end{array}$ & $\begin{array}{r}100 \cdot 0 \\
74 \cdot 0 \\
68 \cdot 0 \\
53 \cdot 0 \\
41 \cdot 0 \\
36 \cdot 0 \\
31 \cdot 0 \\
22 \cdot 0 \\
12 \cdot 0\end{array}$ \\
\hline
\end{tabular}

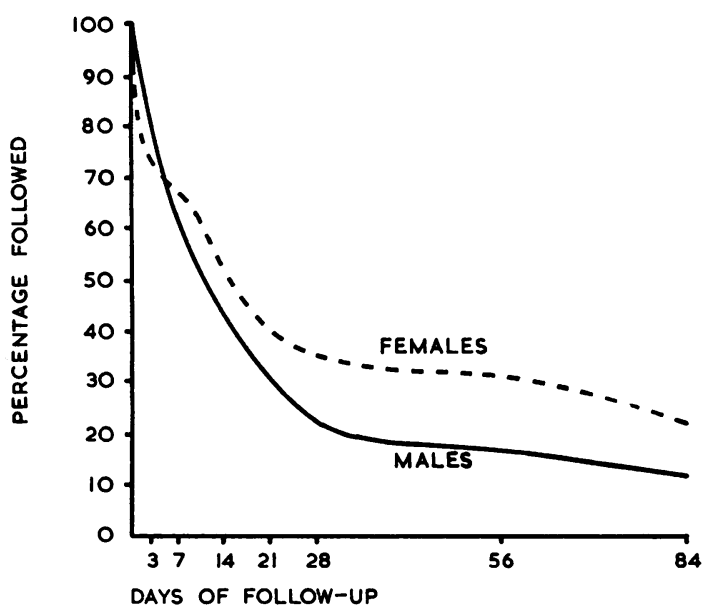

Fig. 9.-Percentage of cases followed-up in a capital city.

Although many of the male patients in whom treatment fails are likely to report back to the clinic, this is by no means the case in females; a proportion of failures is bound to occur in the defaulters who will remain a source of infection.

Indeed, if we assume that patients who are successfully treated, whether followed up or not, and those in whom treatment fails but who return to the clinic do not infect other persons, then the group of defaulters in whom treatment fails constitutes a major factor in the maintenance and increase of gonorrhoea in the community (Fig. 10).

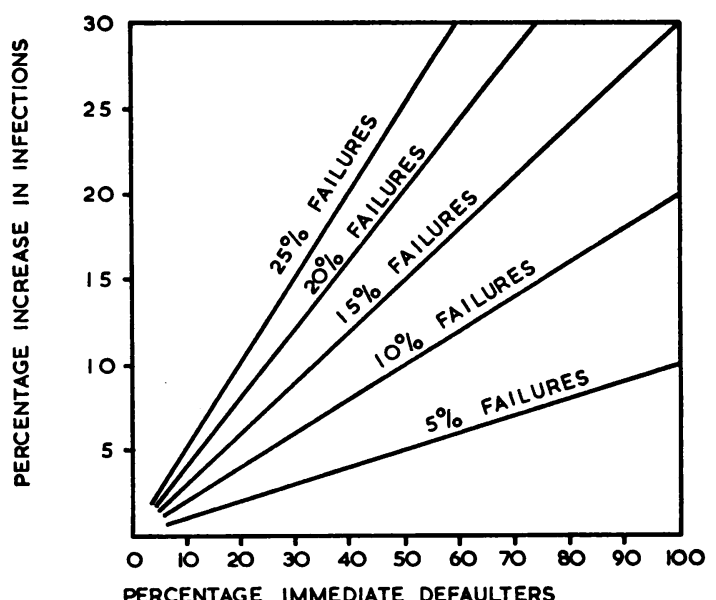

FiG. 10.-Effect of treatment failure rates and immediate default rates on percentage increase in infections. It is assumed for the purpose of this graph that the process can happen twice in one year.

\section{Summary AND Conclusions}

(1) The failure to control gonorrhoea in spite of the introduction of successful treatment, first with sulphonamides and then with penicillin and other antibiotics, has been noted. In England and Wales, in common with many other countries, there has been a significant rise since $1951-1954$, so that by 1960 more cases were being treated in the clinics of England and Wales than in 1925.

(2) Reasons for this failure of control include general factors, social factors, especially in certain problem groups of the population, difficulties in defining the reservoir of infection, and difficulties in the treatment and management of the disease. These points are considered in detail.

(3) An important general factor is that, owing to simplified methods of treatment and the reduced incidence of complications, gonorrhoea is taken less seriously. Repeated infections in a relatively small group are common. Social problems in England and Wales include immigrants, particularly West Indians, who were responsible for only 3 per cent. of male infections in 1952 but for 25.5 per cent. in 1960 . However, there has also been a significant rise in 
cases in persons born in the United Kingdom, and in fact only 54.9 per cent. of the increase between 1952-1958 was accounted for by West Indians.

(4) Teenagers also present a particularly serious problem. In the short period 1957-1960, in those aged 15 to 19 years of age, infections increased by 67.3 per cent. in males and by 65.4 per cent. in females, whereas in those aged 25 and over the numbers increased only by 33.5 and 18 per cent. respectively.

(5) Difficulties in defining the reservoir of infection are outlined. In males casual exposure caused $77 \cdot 2$ per cent. of infections (but only 26.4 per cent. in females). Measures directed against prostitution have less influence on the incidence of venereal disease in a situation in which only 35.7 per cent. of male infections are caught from prostitutes, than in countries where higher figures may pertain.

The limitations of the contact slip as a casefinding tool are considered. Irrespective of the number of slips issued, only 14 to 18 per cent. of contacts may be traced at a particular London clinic.

(6) Recent increases in treatment failure rates, when accompanied by high default rates, may have had a significant effect on the increasing prevalence.

\section{REFERENCES}

Association of State and Territorial Health Officers, American Venereal Disease Association, and American Social Hygiene Association (1959). Joint Statement.

British Co-operative Clinical Group (1956). Brit. J. vener. Dis., 32, 21.

- (1960a). Ibid., 36, 216.

(1960b). Ibid., 36, 233. (1962). Ibid., 38, 1.

Boese, R. (1953). J. Kansas med. Soc., 54, 10.

Brown, W. J. (1961). Bull. Wld Hlth Org., 24, 386.

Bundesen, H. N., Plotke, F., and Eisenberg, H. (1949). Amer. J. publ. Hlth, 39, 1535.

Gjessing, H. C. (1956). Brit. J. vener. Dis., 32, 86.

Haworth, M. C., and Nicol, C. S. (1954). Ibid., 30, 36.

Laird, S. M. (1961). lbid., 37, 70.

Lentz, J. W., Morton, H. E., Garrison, M., and Leberman, P. R. (1953). Amer. J. Syph., 37, 577.

Lodin, A. (1955). Acta derm.-venereol. (Stockh.), 35, 457.

Mahoney, J. F., Van Slyke, C. J., Cutler, J. C., and Blum, H. L. (1946). Amer. J. Syph., 30, 1.

Ministry of Health (1960). Part II, "Report of the Chief Medical Officer for 1959", Appendix C. H.M.S.O., London (Brit. J. vener. Dis., 1961, 37, 74).

Nelson, A. J. (1957). Publ. Hlth Rep. (Wash.), 72, 223.

Rosenthal, T., and Vandow, J. E. (1956). N.Y.St.J. Med., 56, 3154.

Soc. Hyg. News (1959). 34, No. 3, p. 1.

Tottie, M. (1956). Brit. J. vener. Dis., 32, 157.

Towpik, J. (1957). Ibid., 33, 78.

Willcox, R. R. (1958). U.N. int. Rev. criminal Policy, No. 13 , p. 67 .

_ (1961). Bull. Wld Hlth Org., 24, 357. 